\title{
PLANNING AND BUILDING ELECTRIC OF AN FLOWER CARNIVAL CAR AT UNIVERSITY OF DEBRECEN
}

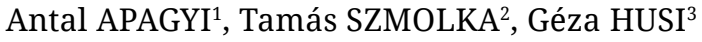 \\ University of Debrecen, Faculty of Engineering, Debrecen, Hungary \\ ${ }^{1}$ apagyi.toni@gmail.com \\ ${ }^{2}$ szmolka.tomi012@gmail.com \\ ${ }^{3}$ husigeza@eng.unideb.hu
}

\begin{abstract}
In this research we will discuss the creation of the flower cart. It will be examined from an economical and environmental perspective. Additionally, the planning process regarding the carrying capacity and battery runtime will be explained. The cart is moved by three-phase electric motors which are controlled by Variable Frequency Drives (VFD). Electric power is supplied by the large battery pack. Overall, the purpose of this vehicle is to be able to participate in the carnival march while increasing the quality of the event.
\end{abstract}

Keywords: VFD, electric, inverter, flower-carnival-car.

\section{Preface}

The flower carnival in Debrecen has been held annually on August 20th since 1966[1]. It's one of the best-known events in Hungary, being linked to the State Foundation Day. On this day in 1083 King Szent István was canonized. For decades it has been a very significant celebration in the city, and has now reached a point where one week before the official carnival, many entertaining programs are held for the public. The aim every year has been to fascinate the spectators with more and more inventive car compositions, followed by dancers and orchestral art groups. Every year the city tries to bring something revolutionary to the table to bring in more and more tourists to this occasion. One such revolutionary addition was the University of Debrecen's completely electric driven flower carnival car, which is completely unique in the history of the carnival. The only thing that can potentially ruin the quality of the show is fuel powered cars. These internal combustion engines are quite noisy and produce exhaust fumes in a huge amounts, polluting the air. The artistic groups marching behind the cars can obviously have a bad experience due to this pollution and noise. The solution is provided by the innovation represented by the University. The University of Debrecen has been a participant in the flower carnival for over a decade but just like every other company they have previously rented traditional cars to join the march. To work around this problem the University decided on building their own electric drive car for the 2016 carnival [2]. The finished product was welcome on its first debut by the organizers and the public. Since the car is completely the property of the University, the maintenance is carried out by a few of the students and teachers in the Faculty of Engineering. Alongside this we are teaching younger students to be able to take over the project on their own in future. For them to be part of this project is as much an honour as it is for us.

\section{Introduction}

\subsection{Comparison between an ordinary and an electric drive}

The main reason behind the fast spread of electric drive vehicles stems from the poor efficiency and environmentally burdening effects of the internal combustion engine. Nowadays, air pol- 
lution is one of the biggest problems, caused by power plants and factories, but mainly by vehicles. The fumes produced are heavily air polluting and also lead to ozone depletion. These effects have motivated people for decades to create improved technologies in the industry.

The diagram of Figure 1. represents very well how the efficiency and fuel economy of diesel engines has improved over the years. Based on studies, the thermal efficiency of a diesel engine is between $30-38 \%$ [3], that of electric motors is still superior, since they have efficiency of around $80-90 \%$. Energy leaves the system mainly in form of thermal losses and in form of various other losses that are responsible for the very poor efficiency of a traditional drive. From an environmental point of view the local harmful emissions of an electric driven car are practically zero.

The air pollution doesn't happen in the living areas in this case, rather in the outskirts at the power plants and factories where electricity and the car parts are created. If we only compare at the course of production, we see that electric car building releases a greater amount of $\mathrm{CO}_{2}$ gas into the air. But after extending the comparison to a car's lifetime, for electric cars we can reach a 51-53\% overall $\mathrm{CO}_{2}$ exhaust reduction.

The $\mathrm{CO}_{2}$ footprint can be reduced even further by using alternative energy sources such as solar energy or wind power. A great advantage of our new technology is that while braking, the motor works in generator mode so that it produces energy from slowing down, Figure 2. [4].

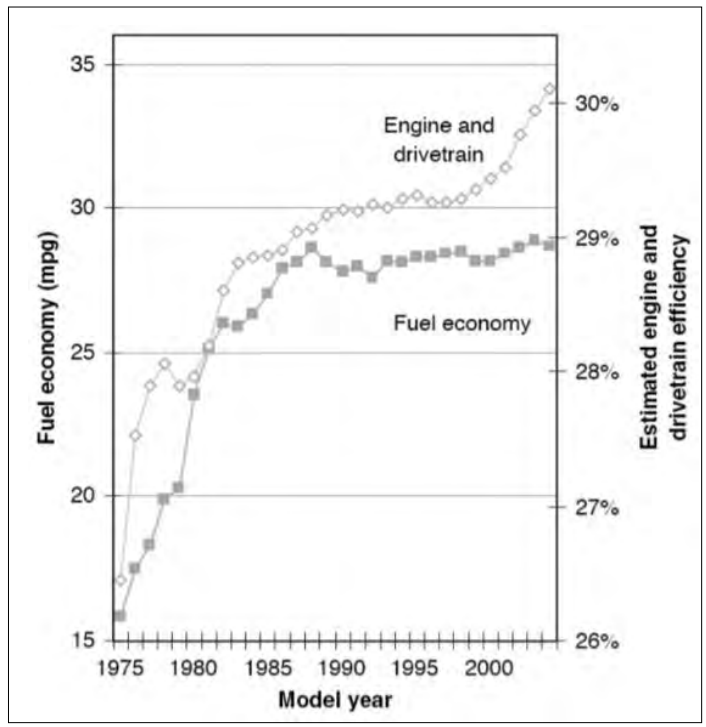

Figure 1. Fuel economy [3]

\subsection{The planning}

ATo our University, innovation has always been a determining value. Nothing represents that better than pushing through such an upgrade. The specific plans were close to complete by early 2016. In finalising the plans the main aspects were reducing the harmful emission and renewing the applied steering system. For the designing of the new chassis, its length and new width were determined by marching route specifications, such as the distance between the tram-stops or the height of the trolley-wire. This is very much needed because the cars pass under routes crossed by electric cables.

\section{The structure of the electric car}

The whole drive is built up around a chosen chassis. Therefore, choosing the correct sized chassis in our project is critical. For us the suitable market is the internal combustion truck's chassis. So, for the carnival car, to make it totally electric we had to make a handful of modifications.

\subsection{The chassis}

Firstly, we needed to decide which undercarriage would be used. The planning requirements were to be able to carry a $4 \times 8 \mathrm{~m}$ sized frame. The frame provides the platform that carries the decoration, such as polystyrene statues with their steel braces, many flowers and turf. The frame is filled up with wooden flooring to provide a safe fastening. In this situation many of the traditional diesel

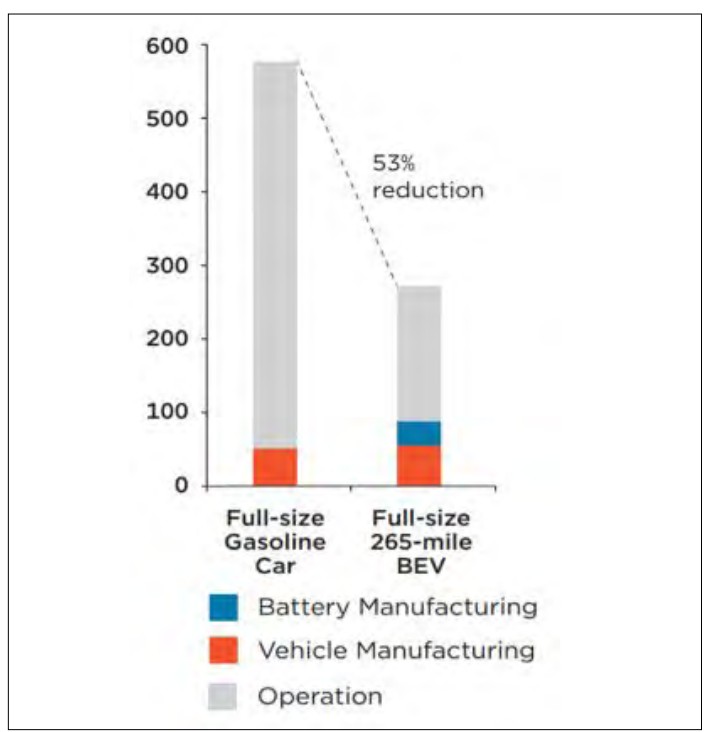

Figure 2. Life cycle global warming emissions 
vehicle parts are no longer needed, so the engine, compressor, hydraulics, tank and steering wheel were removed from the vehicle.

\subsection{Drive and steering}

To make the vehicle operational, we have to replace the removed parts with new elements: two electric motors, one for the drive and one for the steering. The asynchronous motor responsible for the drive chain has $18 \mathrm{~kW}$ power. This sends power through the gear-case to the differential, assuring the movement of the car. The smaller motor which is responsible for the steering is capable of putting out $5 \mathrm{~kW}$ power. This creates a pushing force onto the steering-rod with the help of the Pittman arm that is found on the globoid worm gear. This pushing effect causes the wheels to turn. To avoid damaging the structure, limit switches are applied in the end positions at the Pittman arm cancelling the steering signals. These connections are shown on Figure 3. and 4. [5] .

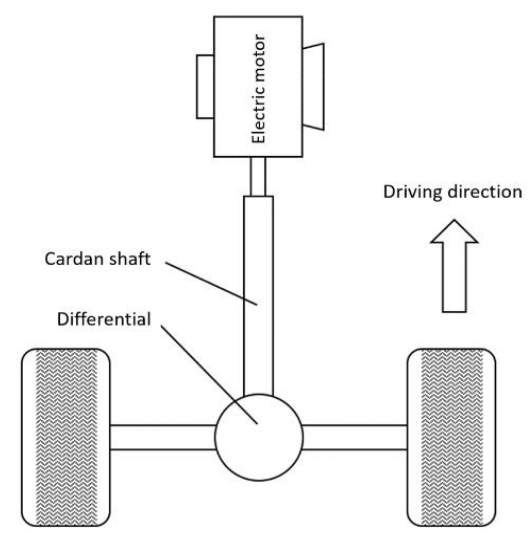

Figure 3. Drivechain

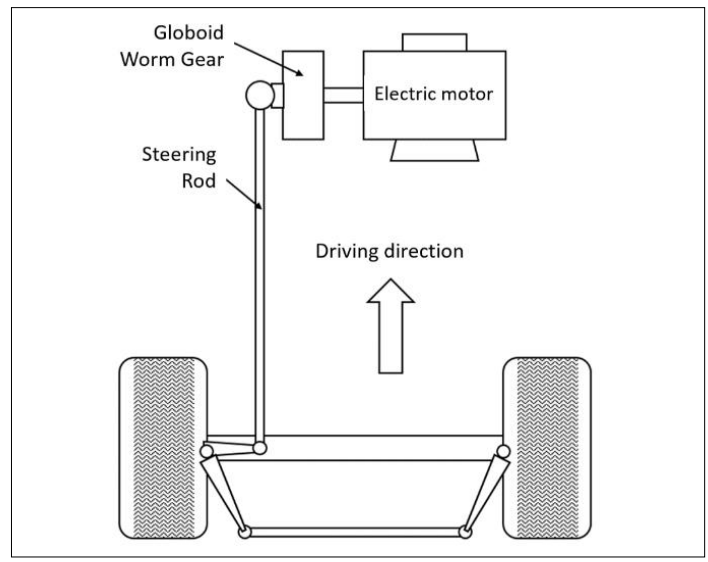

Figure 4. Steering mechanism

\subsection{The control}

The control of the motors is provided by VFDs (Variable Frequency Drives). Since three phase asynchronous motors are used, these VFDs turn the direct current that comes out of the batteries into alternating current. The two motors are controlled by the correct controlling signals fed to the input of the frequency drive by joysticks - which are potentiometers that convert analog signals. This can be changed between $0-10 \mathrm{~V}$ depending on the position of the device, which determines the frequency - the $0-10 \mathrm{~V}$ range is matched by a $0-50 \mathrm{~Hz}$ range. The equal splitting determines the motors frequency causing the change in the driving speed. The steering uses almost the same analogy, but with a small difference: we only care about the direction of the rotation, when the given signal is read, the motor either starts turning the wheels left or right at a previously defined speed So that the joystick responsible for the steering only determines the direction which the motor starts turning not the speed of it.

\subsection{Energy regeneration}

Braking on our vehicle is solved by the provided by the VFD. In the case of induction motors, solving the regeneration is quite easy. The solution comes from the principle of an induction motor. If we create the right amount of torque on the shaft of the motor, while connecting electric load on the poles of the motor, because of the Lorentz force electric current will be generated in the motor. Luckily the VFD includes regenerative braking function, so no circuit building is needed to get this function out of our drive. So-called "braking resistors" are needed to dissipate the energy in form of heat. Since the joysticks have a spring, when this happens, they return to middle position, thus the motor switches to generator mode, slowing down and stopping the vehicle. When shut down, the hand brake is used to hold it in place.

\subsection{Supply}

In the flower car the supply voltage is provided by batteries connected to each other in serial and parallel connection. The car contains 2 different voltage level circuits. The high voltage circuit has 160 cells in it with their serial connection providing $640 \mathrm{~V}$. The low voltage circuit is only $12 \mathrm{~V}$ being built out of 6 cells connected in serial and parallel so as to give $12 \mathrm{~V}$ on their output. This is responsible for the contactors power supply. They cut and 
connect the high voltage circuit to stop or start the car. We applied two indicators during the summer of 2018. This equipment gives feedback about the voltage level and the charging current. To extend the range of the voltmeter a resistor was added serially to the circuit. This was needed because our voltmeter could only measure up to $300 \mathrm{~V}$. After the modification, on the same range we can display $640 \mathrm{~V}$ voltage. The range of the current meter is 10 A so that needed no modification. To make monitoring much easier these indicators were placed in the cockpit. To make sure the implementation was safe, the voltmeter was carefully planned out and built in to avoid any form of malfunction.

\section{Conclusions}

The previous 3 years have been the best proof of the success of this project. On the previous carnivals no incidents occurred and the overall system has been proved to be safe. For now the maintenance work mostly revolves around checking the battery levels year-by-year. With an upgrade to this using BMS (Battery Management System) we could skip the old method of checking the cells one by one. Such a system could make the task of checking and levelling the batteries more correct. It's main advantage is that it would be completely automated. These days there is development going on in regards to the controlling system too. We are trying to implement a wireless remote control. It is a difficult task since we have to view this from many aspects such as the risks that it could give rise to. Implementing this would lead to a much more enjoyable festival experience since the view of these carnival vehicles would not be partially blocked by a driver.

\section{References}

[1] Debreceni virágkarnevál. Történet. (2017. 08 10.). http://debreceniviragkarneval.hu/tortenet/

[2] Dehir: Kétezer akkumulátor hajtja majd az egyetem virágkocsiját - videóval. (2016)

http://www.dehir.hu/debrecen/ketezer-akkumulator-hajtja-majd-az-egyetem-viragkocsijat /2016/07/18/

[3] Nemet G.: Automobile Fuel Efficiency Standards. Historical Case Studies of Energy Technology Innovation In: The global energy assessment. (Eds. Grubler A., Aguayo F., Gallagher K. S., Hekkert M., Jiang K., Mytelka L., Neij L., Nemet G., C. Wilson) Cambridge University Press, Cambridge, UK.

[4] Nealer R., Reichmuth D., Anair D.: Cleaner Cars from Cradle to Grave. Union of Concerned Scientists, 2015, 13.

[5] Kádár L., Varga,F., Kőfalusi P.: Kormányrendszerek jellemző szerkezeti egységeinek elemzése. (2014.)

[6] Bartha I., Vitéz A. Cs., Husi G.: Standard industrial inverter controlled drive chain for various type of EV. (2014). http://hdl.handle.net/2437/228136 